\title{
地下鉄事業者による駐輪場事業の可能性の検討 〜駐輪場所選択と料金支払方法選択の分析を用いて〜*
}

Effectiveness and Feasibility of Bicycle-Parking System Operated by a Subway Company $\sim$ Analyzing Parking Choice Behavior and Payment Method Choice Behavior *

牧 浩太郎 $* *$. 円山玩也 $* * *$. 大森宣暁 $* * * *$. 原田昇 $* * * * *$ By Kotaro MAKI** Takuya MARUYAMA*** $\cdot$ Nobuaki OHMORI ${ }^{* * * *} \cdot$ Noboru HARATA $^{* * * * *}$

\section{1. 研究の背景と目的}

近年、地球環境·都市環境の観点から自転車交通が 見直され、自転車の利用促進が求められている。し かし、駅周辺における放置自転車は全国で約 54 万台

1)に及び、依然大きな社会問題になっている。また、 東京都の実態調査によると、地上駅に比べて地下駅 の周辺では駐輪場実駐車台数に比べて放置台数の割 合が多い2)。

一方、放置自転車対策費は東京都特別区内だけで も年間約 113.7 億円 ${ }^{2}$ にのぼる。そのうえ、豊島区 の「放置自転車等対策推進税」に関する議論にみら れるように、鉄道事業者の協力を得るのも難しい。

よって、特に地下駅周辺において、少ない経費で、 利便性の高い駐輪場を整備する施策が求められると 考えられる。

そこで本研究では、少ない費用で利便性の高い駐 輪場を整備する方策として、「地下鉄事業者による 地下駅の余空間を活用した駐輪場事業」を新たに提 案し、その可能性について検討する。なお、この駐 輪場事業に関しては、事業成立に公的な支援が必要 であると考えられ、また事業が社会的な便益を発生 させると考えられる。そのため、社会的なシステム として利点や実現可能性を包括的に検討する。

本論文の研究フローを示したのが、図ー 1 である。 まず 2 章で、このシステムの詳細と利点を述べる。 この提案を検証するために、3 章で、関連主体を対 象としたヒアリング調査によって、既存の駐輪場の 現状を整理する。それを踏まえて 4 章で、駐輪場所 選択モデルを構築し、シナリオ分析を行なうことに よって、重要なサービス要因と事業成立の可能性を 示す。また 5 章で、料金支払方法選択モデルを構築

\footnotetext{
*キーワーズ : 自転車交通行動，交通行動分析，駐輪場需要

**正会員, 修, 株式会社二菱総合研究所 社会システム研究本部

（广100-8141 東京都千代田区大手町 2-3-6,

TEL : 03-3277-0712, FAX : 03-3277-3462

E-mail : k-maki@mrico.jp)

***正会員, 環境尃, 東京大学大学院 工学系研究科

****正会員, 工博, 東京大学大学院 工学系研究科

*****正会員, 工博, 東京大学大学院 新領域創成科学研究科
}

し、シナリオ分析を実施することによって、採算性 向上策の可能性を示す。

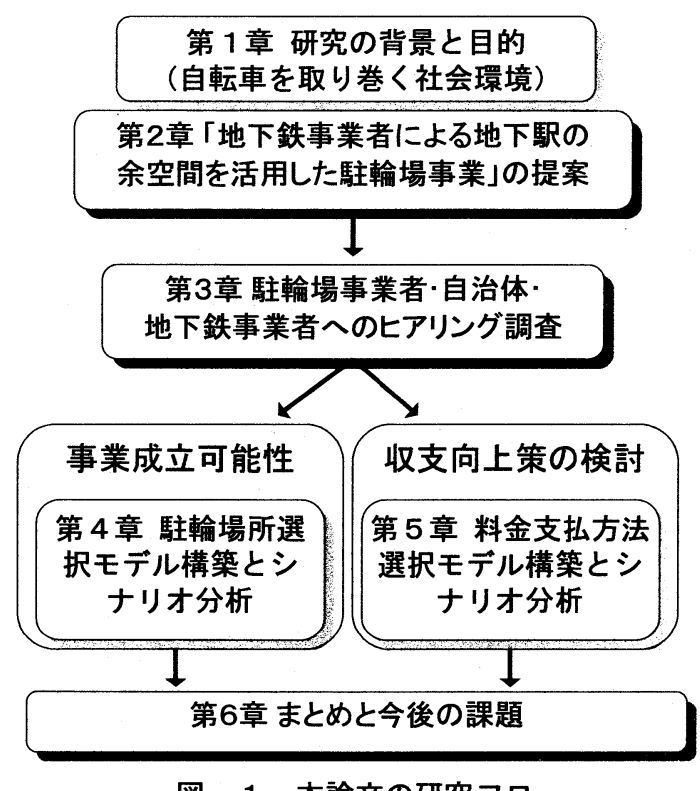

図一 1 本論文の研究フロー

2.「地下鉄事業者による地下駅の余空間を活用 した駐輪場事業」の提案

近年整備された地下鉄の駅は、駅の深度と建設工 法のため、コンコースなどの地下空間に余裕がある ケースが多い。そこで、地下鉄事業者が、関連事業 として駅舎の余空間を利用した駐輪場事業を展開す る施策を提案する。まず、駐輪場に関する 2 つの事 例を紹介し、それらを踏まえて、本論文が提案する 駐輪場事業の利点を主体ごとに整理して示す。

\section{（1）地下駐輪場整備における改善可能点}

東京都では、1990 年に発足した東京道路地下空間 利用連絡協議会において、地下鉄建設時に発生する 駅舎上方の地下空間のうち、地下 $3.5 \mathrm{~m}$ 以下の部分を 埋め戻さずに有効利用することが検討された。その 
結果、大江戸線·南北線・半蔵門線・りんかい線などの 10 数駅で駅舎上に地下駐輪場が整備された。

このとき、地下鉄駅舎（鉄道事業者）と駐輪場（自 治体）で管理者が異なる（消防法上は別棟扱い）た め、駐輪場に 2 つ、駅舎に 2 つエレベータを $1 つ$ の合計 $5 つ も の$ 出入り口を整備しなければならない。 そのため、大江戸線の本郷三丁目駅など 6 駅では、 出入り口 5 力所分の用地を確保できないため、地下 に空間は存在したが、駐輪場建設が見送られた。

また、この方法で整備された駐輪場は、駅舎と別 棟扱いであるため、駅の直近であるにもかかわらず、 地上から改札まで行く際に、階段を 2 回（地上〜駐 輪場〜コンコース）利用しなければならない。

地下鉄事業者が地下駐輪場を管理することになれ ば、消防法によって不要な出口の整備を求められる ことはなく、改札と同じフロアに駐輪場を整備する ことも可能である。よって、駐輪場事業を地下鉄事 業者が駅舎の一部に整備・運営したほうが効率的で あると考えられる。

\section{（2）駐輪場運営における改善可能点}

さらに、民間企業（地下鉄事業者）が駐輪場を整 備・運営することで、経費の削减が期待される。

足立区は、竹ノ塚西口駐輪場の再建·運営に PFI を導入し、駐輪場を区自身が運営するのに比べ 2 割 ほどコストを削減できた ${ }^{3)}$ 。この竹ノ塚西口駐輪場 を現地調查したところ、他の公共駐輪場と異なり、 利用者のニーズにあわせてロッカー・自動販売機等 の関連事業を積極的に行なっていた。

\section{（3）利点の関係主体ごとの整理}

このシステムの利点を関係主体ごとに整理する。 まず利用者は、改札に近く階段の少ない駐輪場を利 用できるものと考えられる。自治体は、民間資本の 活用で、効率的に駐輪場整備を進めることができる だろう。また鉄道事業者は、この駐輪場は利便性が 高くなるため、採算が取れる料金を利用者から徵収 できる可能性がある。

\section{3. 駐輪場事業者·自治体·地下鉄事業者へのヒア リング調査}

次章以降の分析の参考にするために、駐輪場事業 者 5 団体 $($ 表 -1$) \cdot$ 自治体 6 区 (表 -2$) \cdot$ 地下鉄事業 者(営団地下鉄)に対してヒアリング調查を実施した。

\section{（1）駐輪場事業者に対するヒアリング}

民間の駐輪場事業者は、電磁ラックを集中自動清
算方式で管理するコインサイクルパーキング

(CCP) を導入し、駐輪場運営の経費削減を図って いる。CCP を活用した場合、一般的に、収容台数が 500 台以下でも、1 ラックあたりの運営費は月額約 800 円で収まる。収入 (使用料 : 月額 2,000 円程度) から、運営費と、月額約 830 円程度の機材 (ラック・ 清算機等）の減価償却費と、駐輪場用地代・都市計 画税や固定資産税などを除いた残りが、利益になる。

民間の事業者は、人件費の削減・駐輪場の雾囲気 の向上・付加的なサービスなどの収益向上策を重視 している。また、料金・運営形態などの恋更に条例 の改正を必要とする自治体と異なり、状況に応じて 料金・サービスを最適化している。さらに、自治体に よる放置自転車撤去の実施の有無が、駐輪場の新規 展開の重要な判断材料になっていることがわかった。

\section{表-1 各事業者の概要}

\begin{tabular}{|c|c|c|c|c|c|}
\hline \multirow{2}{*}{ 会社名 } & \multicolumn{2}{|c|}{ 業務内容 } & \multicolumn{2}{|c|}{ 管理方式 } & \multirow{2}{*}{ 主な事業内容 } \\
\hline & 管理受言 & 直営 & 有人 & \begin{tabular}{|l|} 
無人 \\
\end{tabular} & \\
\hline $\begin{array}{l}\text { 再開發 } \\
\text { 振興 }\end{array}$ & (?) & 0 & (ㅇ & 0 & \begin{tabular}{|l|} 
自治体から月極駐輪篇理運営を受仛 \\
\end{tabular} \\
\hline 芝園開発 & 0 & (?) & 0 & () & \begin{tabular}{|l} 
通勤通学用コイン \\
パーキング(CCP)
\end{tabular} \\
\hline $\mathrm{NCD}^{* 1}$ & (ㅇ & 0 & $\mathrm{O}$ & (0) & $\begin{array}{l}\text { 商業施設附置駐輪場理の代行(CCP) } \\
\text { 晋) }\end{array}$ \\
\hline $\begin{array}{l}\text { 駐車場 } \\
\text { 整備*2 }\end{array}$ & 0 & ( ) & ○) & 2ヶ所 & $\begin{array}{l}\text { 县成金を利用した駐 } \\
\text { 輪場建設·運営代行 }\end{array}$ \\
\hline 西武鉄道 & - & ( ) & (?) & - & $\begin{array}{l}\text { 線路脇の遊休地(社 } \\
\text { 有地)の活用 }\end{array}$ \\
\hline
\end{tabular}

*1:日本コンピュータ・ダイナミクス株式会社 ○:中心的な莱務領域

*2 : 財団法人 自転車駐車場整備センタ一 $\mathrm{O}$ :副次的な業務領域

- : 展開していない領域

\section{（2）自治体に対するヒアリング}

自治体は、地下駐輪場 1 件の整備に最低でも約 6 億円を投じており、運営費には、収容台数 1 台あた り月額 1,500 円〜2, 000 円を投じている。

大島駅や町屋駅前の地下駐輪場は、地下駅に隣接 するビルの地下階を利用して整備された。そのため、 地下鉄駅と一体で整備された駐輪場と異なり、出入

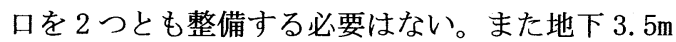
以下にする必要がないため、ベルトコンベアを設置 していない。そのため、運営費が低く抑えられてい る。

また、駅周辺で放置自転車の撤去が行なわれてい ない場合や、無料駐輪場の廃止がされない場合、駐 輪場の利用率が低下している。初台駅周辺では、駅 と直結した地下駐輪場が整備されているものの、出 口から約 50m 離れた隣接する区内では放置自転車の 撤去頻度が低いため、地下駐輪場の利用率が低下し ていることが分かった。 
選択肢間の類似性を考慮して、図一 2 のような 3 レベルのネスティッド・ロジット（N L ）モデルを 仮定した ${ }^{8)}$ 。直交表に基づいて各調查票に 9 設問を 設定したため、分析の有効サンプル数は 3,023 とな った。モデルの推定結果を、表一 4 に示す。

\section{表-4 駐輪場所選択モデルの推定結果}

\begin{tabular}{|c|c|c|}
\hline 説明变数 & 1234 & パラメータ (t值) \\
\hline 雗場所 (反対側) 定数項 & 00 & $-0.903(-8.95)$ \\
\hline 侖料金 (円) & 00 & $-0.023 \quad(-17.19$ \\
\hline 主輪料金 (無料) 定数項 & & 0.639 \\
\hline 自宅-改札間の所要時間 (分) & 10000 & $-0.308 \quad(-8.97$ \\
\hline 融囲気 (明るく整然) 定数項 & 0 & $0.954 \quad($ \\
\hline 妘頻度 (月に 1 回) 定数項 & 0 & $1.677 （$ \\
\hline 去頻度 (毎日) 定数項 & $\mathrm{O}$ & $-2.976(-6.84$ \\
\hline 職業 (学生) 定数項 & 0 & 1.090( \\
\hline 自転車低価格 ${ }^{* 1}$ 定数項 & $\mathrm{O}$ & 0.649 \\
\hline 料金小遣い払い定数項 & 0 & $0.695(3.98$ \\
\hline 長時間駐輪 ${ }^{* 2}$ 定数項 & 0 & $-0.722(-3.87$ \\
\hline 駅周辺来訪頻度（回/週） & O & $-0.273<-4.58$ \\
\hline 雨天時自転車利用定数項 & $\mathrm{O}$ & $-1.102(-4.63$ \\
\hline 選択肢 1 （立体）定数項 & 0 & 0.605 \\
\hline 選択肢 3 (路上) 定数項 & O & $-3.638 \quad(-10.20$ \\
\hline 選択肢 4 (徒歩) 定数項 & $\mathrm{O}$ & 0.892 \\
\hline$\lambda_{2}$ (LOGSUM変数) & & $0.757 \div 10.59$ \\
\hline (LOGSUM変数) & & $0.581 \subset 9.40$ \\
\hline \multicolumn{2}{|l|}{ サンプル数 (回答) } & 3023 \\
\hline \multicolumn{2}{|l|}{$\begin{array}{l}\text { 最終対数尤度 } \\
\text { 尤度比指数 } \rho^{2} \\
\text { E調整済み尤度上 }\end{array}$} & $\begin{array}{c}-3117.57 \\
0.256 \\
0.252\end{array}$ \\
\hline
\end{tabular}

（注）○は、各変数がどの選択肢の効用関数に入るかを示す。

1 は立体駐輸場、2 2 は地下住輪場、3 は路上、4 は徒歩を指す。

${ }^{* 1}$ 自転車低価格 $\cdots 1$ 万円円以下を指す

*2 長時間駐输 $\cdots 8$ 時間より長いことを指す

なお、自宅一改札の所要時間 $(T)$ は、以下のよう に定めた。

$T=t_{b}+t_{p}:$ 立体駐輪場を選択した場合

$t_{b}+1:$ 地下駐輪場・路上放置を選択した場合

（調查票で、駐輪してから改札まで 1 分と設定）

$t_{w} \quad$ : 徒歩を選択した場合

ここに、

$t_{b} \quad:$ 自宅一駅の自転車の所要時間 [分]

（回答者に依存するため、調査票中で質問）

$t_{w}$ : 自宅一駅の徒歩の所要時間 [分]

（回答者に依存するため、調査票中で質問）

$t_{p}$ : 立体駐輪場一改札の所要時間 [分]

(調査票で、 2 分. 6 分· 8 分の 3 通りを設定)

各変数の符号はすべて妥当であり、 $\mathrm{t}$ 值も有意な 值が得られた。 $\lambda_{2}, \lambda_{3}$ より、図一 2 のNLモデル の構造の妥当性が示された。駐輪場の「位置」「雾囲 気」「料金」、路上の「撤去頻度」などの政策変数を モデルに導入することができた。なお、各変数間の 相関は最も高い值でも 0.355 で、多重共線性の問題 は見られなかった。

\section{（3） シナリオ分析}

前節で構筑した駐輪場所選択モデルと平成 10 年 東京都市圈 PT 調査の駅端末手段別乗降客数（豊洲 駅）を用いて、地下鉄事業者が地下駅の余空間を活 用して地下駐輪場を整備・運営した場合の需要予測 を行なった。その需要予測結果をもとに駐輪料金収 入や運営費や機材購入費を求め、後述の建設費や金 利を設定し、駐輪場事業の財務分析として各シナリ オにおける建設費の回収期間（PBP）をもとめた。

\section{（a）設定したシナリオ}

需要予測モデルにおける政策変数は、表一 5 のよ うに設定した。「収益最大料金」とは、各シナリオに おいて料金を 100 円から 10 円ずつ変化させ、駐輪 場の収益が最大になった料金のことである。豊洲駅 利用者数は、平成 10 年の駅利用者数を用いた。

\section{表 -5 設定した政策変数}

\begin{tabular}{|c|c|c|}
\hline & \multicolumn{2}{|c|}{ 〈水準〉 } \\
\hline 位置 & 手前側 & 反対側 \\
\hline $\begin{array}{l}\text { 駐輪場 料金 } \\
\end{array}$ & 100円 & 収益最大料金 \\
\hline 雾囲気 & 明るく整然 & 薄暗く雑然 \\
\hline 路上撤去頻度 & 週に1回 & ほほ毎日 \\
\hline
\end{tabular}

駐輪場事業の財務分析において、まず、駐輪料金 を収入とした。建設費は、福岡市における「博多口 自転車駐車場整備事業」の事例を参考に、3 億円と した。運営費と機材の減価償却費の合計は、ヒアリ ング調査の結果より、 1,700 円/台・月とした。金利は、 市中銀行の長期プライムレートの 5 年平均で、年利 $1.911 \%$ と設定した。

\section{(b) 分析結果}

各シナリオにおける需要予測の結果と回収期間の 推定結果をまとめたのが表一 6 である。表一 6 の推 定結果より、以下のことがわかった。

駐輪場の「位置」「雰囲気」といったサービス水準 を改善することで、回収期間を半減できる。駐輪場 の「料金」を最適化することでも、数年短縮できる。

一方、自治体が支援策として放置自転車の撤去頻 度を「ほぼ毎日」にすると、回収期間を数年短縮で きる。この場合、撤去頻度が「週に 1 回」の場合と 比較して、路上放置の選択者数が $1 / 60$ 以下に減少す るため、撤去頻度を高めても、自治体の撤去費用は それほど高額にならないと考えられる。 
表一 6

各条件下の地下駐輪場利用者数と回収年数

〈収益最大の料金〉

\begin{tabular}{|c|c|c|c|c|}
\hline \multirow{2}{*}{\multicolumn{3}{|c|}{ 駐輪料金 雾囲気 位置 }} & \multicolumn{2}{|c|}{ 撤去頻度 } \\
\hline & & & 週に1回 & ほぼ毎日 \\
\hline & 明るく 手 & 手前 & $¥ 130$ & $¥ 140$ \\
\hline & 整然 & 反文 & $¥ 120$ & $¥ 120$ \\
\hline 萁 & 薄暗〉 & 手育 & $¥ 120$ & $\neq 1$ \\
\hline & 雑然 & 反対側 & $¥ 110$ & $¥ 1$ \\
\hline
\end{tabular}

〈地下駐輪場選択者数〉

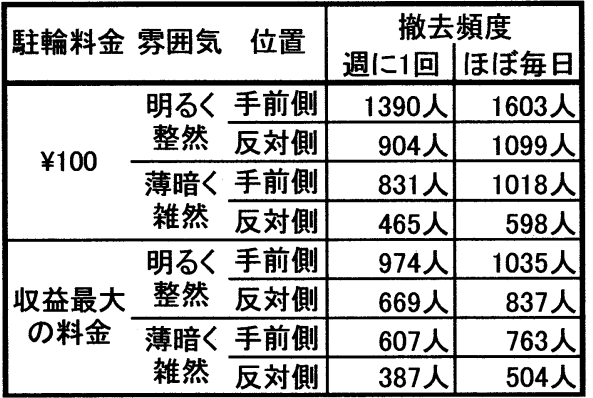

\begin{tabular}{|c|c|c|c|c|}
\hline & & & \multicolumn{2}{|c|}{ 〈回収年数〉 } \\
\hline \multicolumn{3}{|c|}{ 駐輪料金 雰囲気 位置 } & \multicolumn{2}{|c|}{ 撤去頻度 } \\
\hline \multirow{4}{*}{$¥ 100$} & 明るく & 手前側 & 17 年 & 14年 \\
\hline & 整然 & 反対側 & 28年 & 22年 \\
\hline & 薄暗く & 手前側 & 30 年以上 & 24年 \\
\hline & 雑然 & 反対側 & 30 年以上 & 30 年以上 \\
\hline \multirow{4}{*}{$\begin{array}{c}\text { 収益最大 } \\
\text { 料金 }\end{array}$} & 明るく & 手前側 & 14 年 & 11年 \\
\hline & 整然 & 反対側 & 25 年以上 & 19年 \\
\hline & 薄暗く & 手前側 & 29年 & 22年 \\
\hline & 雑然 & 万䇃侀 & 30 年以上 & 30年以上 \\
\hline
\end{tabular}

3 章のヒアリング調査結果より、民間事業者の駐 輪場建設・機材購入などの初期投資の回収期間の基 準が 6 年であることが分かっている。そこで初期投 資を 6 年で回収することを想定すると、約 9,000 万 円〜 16,000 万円不足する。しかし、回収の不足額は、 自治体による一般的な同規模の駐輪場の整備費の約 $13 \%$ 23\%に過ぎない。よって、不足額を自治体が 補助金として提供しても自治体にとって経費を削减 できることがわかった。

\section{5. 料金支払方法選択モデル構築とシナリオ分析}

本章では、民間である地下鉄事業者による収益向 上策の一例として、金沢都市圈で実施されているパ ーク・アンド・ライド (K-Park）を参考に ${ }^{9)}$ 、「改札 と地下駐輪場に隣接するコンビニで一定額の買物を
すれば駐輪料金が無料になる」というサービスを評 価する。駐輪場利用者は、駐輪料金を払うことと、 コンビニで一定額買物をして駐輪場を無料で利用す ることのいずれかを選択することになる。

ここでは、改札に隣接するコンビニも鉄道事業者 が運営していると仮定する。第 3 章第 3 節の「地下 鉄事業者に対するヒアリング」からも明らかなよう に、鉄道事業者がコンビニ等の関連事業を積極的に 展開していることから、この仮定は妥当であると考 えられる。よって、駐輪場とコンビニの間における キャッシュフローは考慮しないこととする。

この形式のサービスに対する利用者の選択行動や サービス実施に伴う収益の変化について研究した既 存研究はない。また、今回の仮定では、駐輪場とコ ンビには改札隣にあるため、駅を利用するトリップ 中に立ち寄る場合は、移動時間や移動費用は無視す ることができる。そこで、店舗選択行動の中でも近 年研究 ${ }^{10)}$ が見られるようになった立ち寄り買物行 動として効用関数を設定することで選択行動を定式 化し、それを用いて収益の変化を評価する。

\section{（1）料金支払方法選択モデルの構築}

\section{（a） 調査概要 $($ 表 -7 )}

表一 7 調查項目

○ 基本的な自転車利用のスタイル (表 3 と同じ)

(ㅇ) 料金支払方法選択に関するSP調查

コンビニ利用の属性に関する設問 :

・現在の、コンビ二の利用頻度 全てのコンビニの利用額

・豊洲駅の改札に隣接するコンビ二ができた場合の、 そのコンビニの利用想定額 他のコンビニの利用想定額

設定した変数とその水準 :

·月額の駐輪料金：

1000 円, 3000 円

・サービス適用の月額下限置物額：

2000 円，4000 円，7000 円，11000 円，16000 円

(๑) 個人属性

(表3と同じ)

料金支払方法選択モデル (binary logit model) を構築するための SP 調查を、表一 3 のアンケート調 查にあわせて実施した。モデルでは、必ず駐輪場を 利用するという仮定のもと、駐輪料金を払うこと

(「料金払い」) と、サービス「改札に隣接するコン ビニで一定額以上の買物をすれば、駐輪料金は無料」 の利用（「買物」）の 2 項選択を想定する。 


\section{(b) モデルの推定}

以下の 2 通りの方法で買物金額を効用関数へ導入 することを検討した。

\section{A 線形型関数}

サービス適用に必要な買物金額と現状のコンビニ 利用額の差額を説明変数「追加買物額」として導入 した。

B 折れ線型関数

「サービス適用に必要な買物金類」と、個人の「改 札隣のコンビニの利用想定額」や「その他のコンビ 二の利用想定額」の大小関係によって、個人の店舗 選択行動の状況は異なる。また、図一3のように、 選択行動の違いによって効用の変化にも違いが生じ る。すなわち、

(1) サービス適用に必要な買物金額がそのコン ビ二の利用想定額より少ない場合、サービ スの有無がコンビニ選択にほとんど影響を 与えない。つまり、必要な買物金額が設定 されても、効用はあまり低下しない。

(2) 必要な買物金額が、そのコンビニの利用想 定額より多く、全てのコンビニの利用想定 額より少ない場合、買物を他のコンビニか ら移転させる。買物するコンビニを変更し た分、効用が低下する。

(3) 必要な買物金額が、全てのコンビニの利用 想定額より多い場合、買物をコンビニ以外 から移転させることになる。そのため、効 用が大きく低下する。

(4) それに対して駐輪料金として支払う場合、 商品が得られないため、効用がさらに大き く低下する。

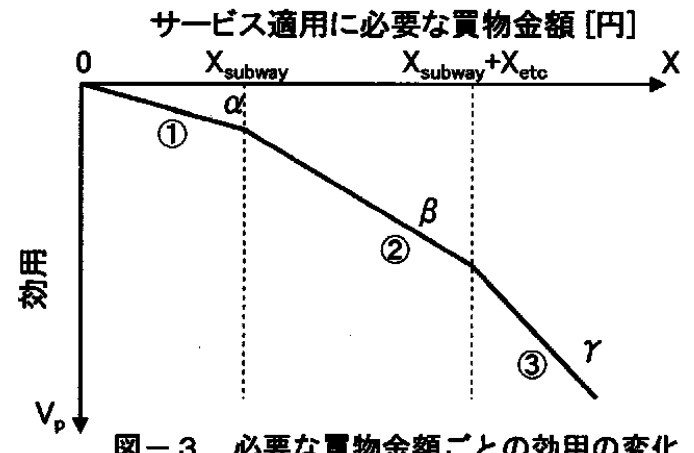

そこで、買物金額に関する部分効用関数を、サー ビス適用に必要な買物金額の大小で 3 分類し、以下 のように定義した。

$$
V_{p}=\left\{\begin{array}{c}
\left.\alpha X \quad \text { if } \quad X \leq X_{\text {subway }}\right) \\
\alpha X_{\text {subway }}+\beta\left(X-X_{\text {subway }}\right) \\
\text { if } X_{\text {subway }}<X \leq X_{\text {subway }}+X_{\text {etc }} \\
\alpha X_{\text {subway }}+\beta X_{\text {etc }}+\gamma\left(X-X_{\text {subway }}-X_{\text {etc }}\right) \\
\text { if } X_{\text {subway }}+X_{\text {etc }}<X
\end{array}\right.
$$$$
\text { ここに、 }
$$

$V_{p}:$ 買物金額に関連する部分効用関数

$\alpha, \beta, \gamma:$ 未知の推定すべきパラメータ

$X_{\text {subway }}$ : 改札隣のコンビニの利用想定額 (円/月)

$X_{e t c} \quad$ : その他のコンビニの利用想定額 (円/月)

$X \quad$ : サービス適用に必要な買物金額 (円/月）

よって、図ー3のように、各パラメータ間には、 $\alpha \geq \beta \geq \gamma \geq \delta$ ( $\delta$ : 駐輪料金のパラメータ) という 関係が成り立つと予想される。

ロジットモデルの各パラメータの推定結果を、表 -8に示す。

表－8 料金支払方法選択モデルの推定結果

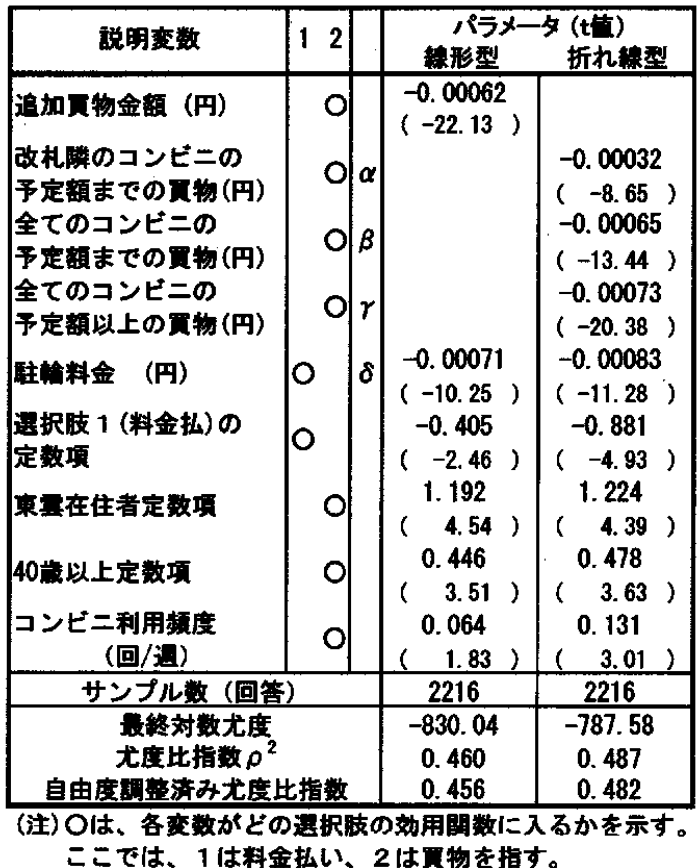

各変数の符号はすべて妥当であり、 $\mathrm{t}$ 值も有意な值 が得られた。折れ線型のほうが、説明力が強く、上 記の仮説通り $\alpha \geq \beta \geq \gamma \geq \delta$ の関倸になった。よって、 以降では折れ線型関数を用いる。 


\section{（2） シナリオ分析}

SP 調査の回答者をサンプルとして、「駐輪料金」 と「サービス適用に必要な買物金額」を変化させて、 駐輪場の収入の増减のシナリオ分析を行なった。

\section{（a）設定したシナリオ}

コンビニの粗利益率を $30 \%$ と仮定した。「駐輪料 金」は 200 円ずつ、「サービス適用に必要な買物金 額」は 500 円ずつ変化させた。

\section{(b) 分析結果}

「駐輪料金」と「サービス適用に必要な買物金額」 を変化させて「駐輪場の収入の増減」を求めたのが、 図ー4である。 X 軸が「サービス適用に必要な買物 金額」、Y 軸が「駐輪料金」であり、Z 軸が 2 変数に よる「駐輪場の収入の増減」である。図一 4 より、 条件によっては収入が増加することがわかり、特に 駐輪料金が 1,000 円で必要な買物金額が 7,500 円の ときに収入が最大になった。このとき、駐輪場利用 者の $12.2 \%$ がこのサービスを利用し、収入は $2.9 \%$ 増加するという結果になった。

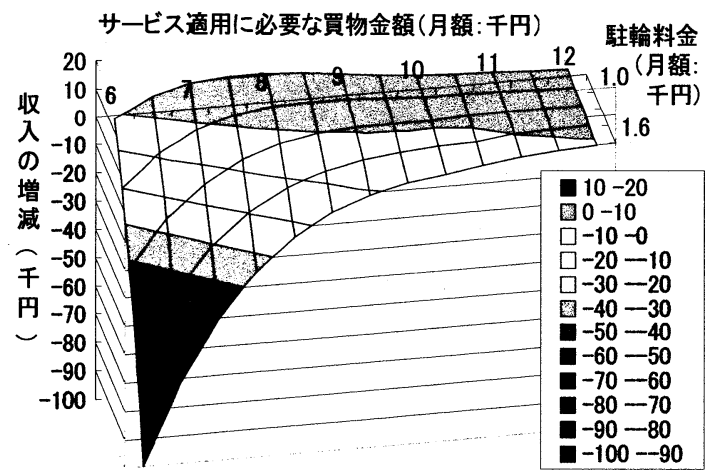

図-4 駐輪料金と必要な買物金額 の変化による収入の増減

\section{6. まとめと今後の課題}

本研究では、「地下鉄事業者による地下駅の余空 間を活用した駐輪場事業」を提案し、自治体によっ て整備・運営される駐輪場に比べて過㮃な整備の必 要がなく、利便性が高く、運営も効率化されること を示した。また、地下鉄事業者が運営することによ って向上するであろう駐輪場の「位置」「雰囲気」 「適切な料金」が経営に重要であることを示した。 そして、自治体が自ら整備する場合の建設費の約 $13 \%$ ～23\% 補助金として地下鉄事業者へ提供す
れば、民間駐輪場事業者が初期投資回収の期限とす る 6 年で回収することができることを示した。最後 に、小売店との提携という公共駐輪場では困難であ った収益向上策によっても、駐輪場の採算性を向上 できることを示した。

本研究で示した結果は、SP データを用いた分析 によるものである。SP データの信頼性には限界が あり、これらの結果の数值は慎重に解釈されるべき である。しかしながら、今回のように現実に存在し ていないシステムの分析においては、SP データに 頼らざるを得ない。また、そのシステムの有効性に ついていくつかの有用な知見を得ることができた意 義は大きいといえるだろう。

今後の課題としては、「地下鉄事業者による駐輪場 事業」の構造物としての実現可能性や安全性の検討 がなされるべきである。また、既存のエレベータを 利用して駐輪場用のスロープを設置しないなどの代 替案も検討寸べきである。事業評価に関しては、社 会経済的な評価を行なうことが望まれる。

参考文献

1 ) 内閣府政策統括官（総合企画調整担当）付交通安全対 策担当: 駅周辺における放置自転車等の実態調查の集計 結果, 2002.

2 ) 東京都生活文化局 : 駅前放置自転車の現況と対策, 2003.

3) 市川嘉一 : 曲がり角迎えた自治体の放置自転車対策, 日経地域情報, 396 号, pp.1-21，2002.

4 ) 松岡淳, 外井哲志, 梶田佳孝, 清田勝 : 都心部におけ る駐輪場所選択要因の把握とモデルの構築に関する研 究, 第 23 回交通工学研究発表会論文報告集, pp.237-240, 2003.

5 ) 鈴木紀一, 高橋勝美, 兵藤哲朗 : 自転車走行環境に着 目した鉄道端末自転車需要予測方法の提案，交通工学， Vol.33, No.5, pp13-21, 1998.

6 ) 椿高範, 原田昇, 太田勝敏 : 心理的要因を加味した駅 前駐輪行動時の社会的費用に関する研究, 土木計画学研 究・講演集, Vol.26, CD-ROM， 2002.

7 ) 内田武史, 細見昭, 黒川洸 : 違法駐輪に関する意識を 考慮した自転車利用者の駐輪場所選択行動特性分析, 土 木計画学研究・論文集, Vol.19, No.3, pp.409-414, 2002.

8 ) Ben-Akiva,M, Lerman,SR : Discrete Choice Analysis, The MIT Press, 1985.

9 ) 中島正人 : 城下町金沢の都市交通政策一金沢における 交通需要マネジメント施策とオムニバスタウン計画, 運 輸と経済，第 60 巻，第 7 号, pp.28-35, 2000.

10 ) 例えば、徳永直子・貞広幸雄 : 立ち寄り利用施設の 選択要因に関する研究 一ATM 一例として一, 人 間・環境学会第 9 回大会講演梗概集，2002 


\section{地下鉄事業者による駐輪場事業の可能性の検討 \\ 〜駐輪場所選択と料金支払方法選択の分析を用いて〜*}

牧 浩太郎**. 円山玩也 ${ }^{* * *} \cdot$ 大森宣暁 $* * * *$. 原田昇 $* * * * *$

本論文では、「地下鉄事業者による地下駅の余空間を活用した駐輪場事業」を提案し、利点と実現可能 性の検討を行なった。ヒアリング等の駐輪場の実態調査から、この駐輪場は自治体によって整備・運営さ れる駐輪場に比べて過剩な整備の必要がなく、利便性が高く、運営も効率化されることを示した。 S P 調査に基づく駐輪場所選択モデルを構筑して行なったシナリオ分析から、地下鉄事業者が運営すること により向上するであろう駐輪場の「位置」「雾囲気」「適切な料金」が経営に重要であることを示した。 料金支払方法選択モデルを構筑して行なったシナリオ分析から、小売店との提携という収益向上策によ って駐輪場の採算性を向上できることを示した。

Effectiveness and Feasibility of Bicycle-Parking System Operated by a Subway Company $\sim$ Analyzing Parking Choice Behavior and Payment Method Choice Behavior *

By Kotaro MAKI** - Takuya MARUYAMA ${ }^{* * *} \cdot$ Nobuaki OHMORI ${ }^{* * *} \cdot$ Noboru HARATA $^{* * * * *}$

In this paper, we propose a bicycle-parking system operated by a subway company. Interview surveys show that the parking system can be more efficient than that operated by a local government. A parking choice model estimated with SP survey and the scenario analysis show that the "place", "regularity" and "fee" of the parking are important for the profitability of the system. A payment method choice model and the scenario analysis show that cooperation with a retail store next to the parking makes the system more profitable. 